The History of Human Rights 
This page intentionally left blank 


\section{The History of Human Rights}

From Ancient Times

to the Globalization Era

With a New Preface

Micheline R. Ishay

\section{甲}

UNIVERSITY OF CALIFORNIA PRESS

Berkeley · Los Angeles · London 
University of California Press, one of the most distinguished university presses in the United States, enriches lives around the world by advancing scholarship in the humanities, social sciences, and natural sciences. Its activities are supported by the UC Press Foundation and by philanthropic contributions from individuals and institutions. For more information, visit www.ucpress.edu.

University of California Press

Berkeley and Los Angeles, California

University of California Press, Ltd.

London, England

(C) 2004, 2008 by Micheline R. Ishay

Excerpt from The Origins of Totalitarianism by Hannah Arendt, copyright (C) I973, I968, I966, I958, I95 I, I94 8 by Hannah Arendt, copyright renewed by Mary McCarthy West, reprinted by permission of Harcourt, Inc.

ISBN 978-0-520-2564I-5 (pbk. : alk. paper)

The Library of Congress has cataloged an earlier version of this book as follows:

Library of Congress Cataloging-in-Publication Data

Ishay, Micheline.

The history of human rights : from ancient times to the globalization era / Micheline R. Ishay.

p. $\mathrm{cm}$.

Includes bibliographical references and index.

ISBN 0-520-23496-O (alk. paper).

ISBN 0-520-23497-9 (pbk. : alk. paper)

I. Human rights-History. I. Title.

JC57I.I73 2003

$323^{\prime} .09-\mathrm{dc} 2 \mathrm{I}$

2003012769

Manufactured in the United States of America

I6 I 5

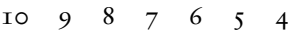

The paper used in this publication meets the minimum requirements of ANSI/NISO Z39.48-I992 (R I997)

(Permanence of Paper).@ 
For David,

Adam, Elise, and their generation 
This page intentionally left blank 